\title{
Zhengzhou - Political economy of an emerging Chinese megacity
}

\begin{abstract}
Zhengzhou is one of the fastest growing cities in China, but has attracted comparatively little international attention. This paper charts the contemporary transformation of Zhengzhou and highlights some of the challenges that arise from its recent growth. It demonstrates the rise of Zhengzhou from small town to megacity. This transformation has occurred in less than seven decades with Zhengzhou benefiting from its geographic importance and its position as a provincial capital in China's hierarchical system of government. While western accounts typically focus on the role of market forces and agglomeration economies in explaining the rise of megacities, we show the role of political decisions in explaining the growth of Zhengzhou as an international centre for manufacturing, commerce and logistics. The paper concludes that innovation and reform in regional governance, particularly to deal with emerging challenges, are necessary, if it is to develop a well-functioning megacity.
\end{abstract}

\section{Keywords}

Zhengzhou, Emerging Megacity, EuroAsian Transportation and Logistics Hub, International Capital of Commerce

\section{Introduction}

In 2016, the Economist Intelligence Unit identified Zhengzhou as one of the fastest growing cities in China. But Zhengzhou is a city which has attracted comparatively little international attention. Although the city has a long history, it is only in recent years it has grown at exponential rates. By 2017, Zhengzhou reached a population of 9.88 million (ZZSB, 2018), just short of megacity status - defined by the UN Department of Economic and Social Affairs as urban agglomeration of over 10 million people. In this paper, we chart the contemporary transformation of Zhengzhou and highlight some of the challenges that arise from its recent growth. When Zhengzhou became the capital of Henan province in 1954, it had a population of 160,000 . Today's city would be scarcely recognisable to residents from that time.

Nevertheless, despite the scale of recent change, Zhengzhou remains deeply shaped by its past. On the face of it, the growth of megacities is the outcome of agglomeration economies arising from the market processes, in which interventions in land-use planning typically hinders urban growth by restricting processes of economic concentration (Pike et al, 2017). But, the story of Zhengzhou highlights the importance of political decision-making and the role of economic, social and land-use planning in shaping urban development in China. Hence, in this paper we focus on the political economy of the city's growth. Agglomeration processes have certainly shaped the recent development of Zhengzhou, but the role of political decision has been crucial. We show how, as capital of the province of Henan, 
Zhengzhou's development been heavily shaped by the actions of national, provincial and local governments. In the remainder of this paper we describe, first, the historical geography of the city, second, the development of the city under central planning, the impact of more market-oriented forms of development and Zhengzhou's current ambitions to act in the global arena.

\section{Historical geography of Zhengzhou}

Zhengzhou (also known as Chengchow in the 19th and the first half of 20th century), as the capital of Henan, is the political, economic, technological, and educational centre of the province, China's most populous province, containing more than 100 million. Located on the southern bank of the middle reach of the Yellow River (Figure 1), the city is recognised as one of the eight great ancient capitals of China. Historically, the rise and fall of Zhengzhou has been closely linked to its position as a transportation hub because of its geographical location. Its modern renaissance was brought about by its emergence as an important railway junction in the first decade of twentieth century establishing its position as a commercial and trading centre in central China (ZZCEG, 1990).

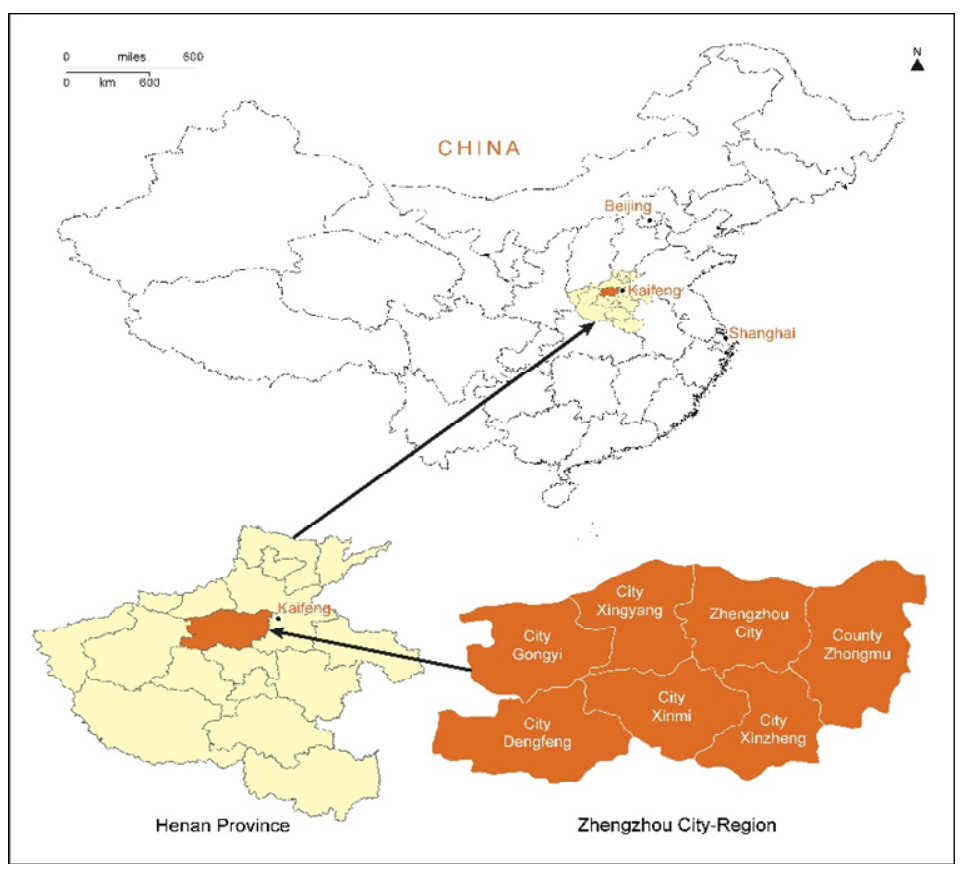

Figure 1 Location of Zhengzhou

Source: Author developed based on Henan GIS data

The earliest history of Zhengzhou can be traced back to some 3500 years ago when it was the national capital of the Shang dynasty (1600 BC-1046 BC). Archaeological excavation has shown the city already had a built-up area around $16 \mathrm{~km}^{2}$ which was well planned, walled, and protected by a moat. It became a regional centre when the Shang moved their 
capital to elsewhere due to natural disaster and war around BC 13th century. During the following eight centuries or so, the development of agriculture in Zhou dynasty (1046 BC 256 BC) made it possible for nomadic tribes to settle and form feudal states (ZZCEG, 1990). Zhengzhou served as either the capital of vassal states or fiefdoms throughout the Zhou period. Under China's first emperor in the Qin dynasty (221 BC-206 BC), it became a county town. Since the Han dynasty (202 BC - AD 220), either Xi'an (Chang'an) or Luoyang was the principal capital until the Song dynasty (AD 960 - AD 1279). The enlargement of the Chinese territory and the relative development of eastern and southern regions favoured Zhengzhou's geographical position and it emerged as centre for agricultural products and handicrafts. By Sui dynasty (AD 581 - AD 618) the name of Zhengzhou was first officially chartered and the city became the seat of a prefectural administration under the direct control of the emperor. Later, Zhengzhou occupied a strategic position on the Grand Canal, supplying food and handicraft products from the south and east to the capitals at Luoyang and/or Chang'an to the west and the frontier armies to the north. Since the Northern Song (960 - 1127), however, the move of the capital eastward to Kaifeng, then southward to Hangzhou, Nanjing and northward to Beijing reduced the importance of Zhengzhou. But, the city had always served as the seat of either a prefectural or county administration.

Zhengzhou's position as a major transportation hub was reinvented by the intersection of China's two major railways in the first decade of the $20^{\text {th }}$ century, reasserting the importance of its geographical location. When Pinghan Railway, the North-South artery linking Beijing and Hankou, intersected with Longhai Railway, the main West-East railway connecting Kaifeng and Luoyang, the city became a regional centre for commerce and trade, particularly for cotton, grain, peanuts, and other agricultural products (Liu, J., 1984 (1929)). Shigejiro Hayashi (1921), a Japanese economist predicted Zhengzhou would become a Chinese Chicago. The Travel Magazine <旅行杂志〉, the most influential tourist magazine in China in the 1920s, referred to Zhengzhou as a major metropolis in northern China. However, the subsequent civil war and Japanese invasion during the 1930s and 1940s had almost destroyed the city. By the time the People's Republic of China (PRC) was founded, the city had a population of 164,000 , while the built-up area shrank to under $5.23 \mathrm{~km}^{2}$ (Wang, X. S., et al., 2005).

\section{Urban development before the 1984 urban reform}

The establishment of the PRC marked the start of a new stage of development for Zhengzhou. The communist government followed China's tradition of maintaining several tiers of sub-national government but reinforcing its centralisation and hierarchical top-down control. Taking advantage of its position as the national railway hub, Zhengzhou replaced Kaifeng as the provincial capital in 1954, which, in the context of top-down control over resources allocation, placed the city in a privileged position over Kaifeng and other cities in Henan. On the one hand, being transformed from a county town to a provincial capital, Zhengzhou was radically enlarged by the relocation of provincial government and upgrading the municipal government to prefectural level. On the other hand, benefitting from its geographical location and provincial capital status, the city was selected by the central 
government as one of 15 favourable cities across the country to be primarily supported by the central state for development (Liu, Yanpu, 1988).

Under the new policy, Chinese cities were either established as, or transformed to become, production centres. In addition to its function as the political and administrative centre of Henan province, Zhengzhou was also planned to develop towards a city that would focus on producing industrial equipment and light industrial products. Benefitting disproportionately from these redistributive policies, several textile factories and other manufacturers were either moved to or founded in Zhengzhou during the first and second "Five-Year Social and Economic Development Plan (FYP) (1952-1961)" period. This laid the foundation for the city's subsequent development, but also created a path dependency for the development in the immediate post-reform period.

A very constrained industrial base emerged as a result of these policies. Rather than expanding the capacity or productivity of the existing unit of factories, new investment was mainly used to build new factory units, often producing similar products. For example, the five central state-owned textile mills built in the then western suburbs between 1954 and 1959 brought more than 100,000 skilled workers from Shanghai and other eastern cities to Zhengzhou. By 1959, the industrial output by the six mills ${ }^{1}$ reached RMB 450 million (US\$ 171.95 million) at present value and generated $60 \%$ of Zhengzhou's total tax revenue (Wu \& Zhang, 2009).

Zhengzhou's urban expansion or economic growth during the early period of PRC relied predominantly on the creation of factory units and public agencies - government bodies, central state-owned enterprises (SOEs), local SOEs, and local collective-owned enterprises known as "work units". While the relocation of provincial government brought about 190,000 population to the city, the consolidation of its role as a major national transportation hub added another 150,000 to the city. Following on this path, within less than 10 years, the city's built up area expanded to $71 \mathrm{~km}^{2}$ with a registered population of 673,000 (ZZMG, 1989).

This model of urban development, however, was associated with problems. First, urban economic growth relied only on building factories units. There was no incentive to expand production at existing factories because profits and taxes generated were appropriated by the state and rarely reinvested. Taking the textile industry as an example, from 1954 to 1959 , when there was a new factory founded every year it saw the record growth of annual industrial output. However, the growth of their industrial output slowed down significantly when there was no new factories were added after 1959 (see Table 1).

Table 1: The Average Annual Growth Rate of the Five Textile Mills in Zhengzhou between 1954 and 1985 (\%)

\footnotetext{
${ }^{1}$ Five newly founded plus one pre-existing which was private owned but confiscated by the state after the communist revolution.
} 


\begin{tabular}{|c|c|c|c|c|}
\hline & $\begin{array}{l}\text { Industrial } \\
\text { output }\end{array}$ & $\begin{array}{l}\text { Profit } \\
\text { and Tax }\end{array}$ & $\begin{array}{l}\text { Labour } \\
\text { Productivity }\end{array}$ & Main Attribute \\
\hline 1954-1959 & 100.31 & 134.68 & 19.29 & $\begin{array}{l}\text { One new factory added every year } \\
\text { from } 1953 \text { to } 1958\end{array}$ \\
\hline $1960-1962$ & -30.76 & -29.38 & -20.90 & Great famine \\
\hline 1963-1966 & 34.13 & 31.48 & 21.81 & Recovery from the great famine \\
\hline 1967-1976 & -2.18 & -6.08 & -5.03 & Cultural Revolution \\
\hline 1977-1979 & 27.90 & 49.39 & 35.11 & Recovery from Cultural Revolution \\
\hline 1980-1985 & 2.16 & -10.27 & -2.05 & $\begin{array}{l}\text { Number of employees doubled as a } \\
\text { result of absorbing redundant workers } \\
\text { and existing employees' family } \\
\text { members who were sent to rural areas } \\
\text { during Cultural Revolution while } \\
\text { product lines remain unchanged and } \\
\text { private competitor emerged }\end{array}$ \\
\hline
\end{tabular}

Sources: Author collected and compiled from Factory Records of the Five Textile Mills in Zhengzhou

Second, under the centrally planned economy, being designated as a national key city meant more SOEs located in the city than elsewhere. The politicisation and direct control of SOEs by the central authorities resulted in the marriage of local economic development and national politics. As shown in Table 1, the growth and decline of textile industry which was once the dominant pillar of Zhengzhou's economy was closely linked to the major political movements in the country. Because the profit and tax generated by SOEs were taken directly by the central authorities, the city found hard to provide infrastructure and services to the naturally increased urban population.

\section{Urban development in the post-1984 urban reform period}

China's contemporary urban reform began in 1984, following the rural reforms in 1978. However, cities faced enormous pressure immediately after the end of Cultural Revolution, including providing accommodation and employment to tens of millions of returnees who had been sent to the countryside by the government since the "Anti-Right Wing Movement" started in 1957. The inability of state alone to meet such demand led to the unintended invention of the "dual-track system" allowing coexistence of the traditional plan system and an emerging market sphere (Naughton, 1996, p.8). Under such dual mechanisms, while the state plan still dominated the allocation of resources, all work units, including government departments and agencies, non-profit making public sectors, individuals, and even the military, could set-up self-funded enterprises outside the state plan. Following the same principle, SOEs could make and keep marginal profits. For the government, this was a solution through which employment opportunities could be created and funds raised for improving and creating housing. Zhengzhou followed this trend. Almost every work unit 
established subordinated enterprises using the public funds it controlled to employ its affiliated family members. Meanwhile, the city once again benefited from its textile industry which not only absorbed 100,000 redundant workers, but also provided over 60,000 additional jobs to the city (Wu \& Zhang, 2009). This "growing out of the plan" pattern of development, as described by Naughton (1996), enabled Chinese cities in general, and Zhengzhou in particular, to avoid a potentially disastrous crisis.

The urban economic reform coincided with a shift of regional policy from a redistributive approach to one which followed more market principles. However, central government continued to play a dominant role in what is now called "Socialist Market Economy". Instead of directly creating SOEs, state intervention came in the form of an enhanced role for local governments in economic development with policy incentives and financial support from the central government. While policy incentives, such as Special Economic Zones, open cities for foreign direct investment and free trade, tax breaks, and so on, were exclusively applied to the designated coastal cities, funding support from the central government was used to improve urban infrastructure in these cities. As an inland city, Zhengzhou lost its favoured position. Meanwhile, the transition to a market economy in the coastal regions started with allowing foreign and private investment in light industries, particularly textiles. This led to textile industry soon becoming the most competitive sector in the country in the initial period of the reform. State owned textile factories began to struggle. Relying heavily on the textile industry, Zhengzhou's economy suffered severely, resulting in growth rates slower than other inland cities whose economies were dominated by heavy industries, such as Wuhan and Changsha. Figure 2 presents a comparison of GDP growth rates between Zhengzhou and other comparable provincial capitals in the last four decades, showing Zhengzhou failed to keep pace with rapid growth elsewhere. Zhengzhou's experience emerges as quite distinctive in the broader Chinese context.

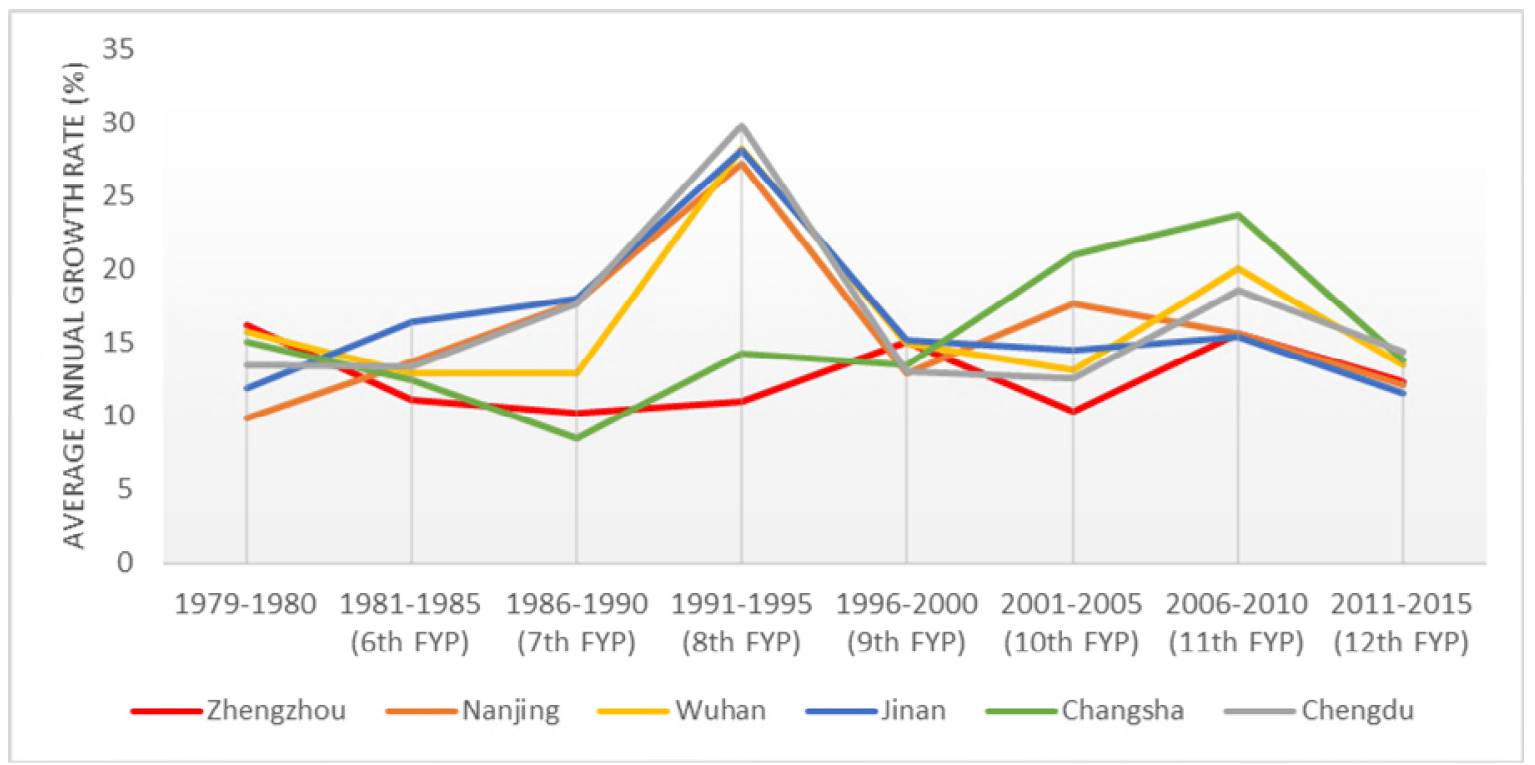


Figure 2 Average Annual growth rate of GDP in selected provincial capitals in China

Source: Author compiled from Statistic Yearbooks (various years) and Five-Year Social Economic Development Plans (FYP) of the six cities

In the initial period of reform in the 1990s, Zhengzhou, however, was marked as a national pioneer in the reform of state monopoly in commercial sector. Taking the advantage of its role as a transport hub, numerous large wholesale markets for redistributing both production and consumer goods developed spontaneously in the eastern fringe of the city, close to the railway freight station. At the same time in the old centre of the town, several large modern department stores and malls funded by private or collective sector started to compete against state-run stores. As SOEs struggled, the unexpected emergence and rapid growth of the non-state commercial sector led to Zhengzhou being designated a "prosperous city for commerce and trade" (Qin, 1992).

The immediate success of experimental marketisation and openness in the selected coastal cities led the inland regions to duplicate the policy, although without official endorsement from the central government. Following the model of special economic zones, local governments competed to create economic and technology development zones (ETDZ) and/or high technology development zones (HTDZ), which resulted in the national wide "ETDZ/HTDZ frenzy" in the 1990s. In this round, Zhengzhou managed to establish both an ETDZ and HTDZ in the south-eastern and north-western suburbs with planned areas of $12.49 \mathrm{~km}^{2}$ and $18.6 \mathrm{~km}^{2}$ respectively (Liu, Ying, et al., 2008). The ETDZ and HTDZ in Zhengzhou were nevertheless not as successful as expected in terms of attracting inward investment in their earlier stage. It was not until manufacturers and higher education institutions relocated in to release land in the city centre for property development, that occupancy rates in both zones started to increase.

\section{Explosive urbanisation since 2000s}

At the turn of the millennium, a radical shift in urban policy occurred, which emphasised the role of cities as drivers of economic growth (China State Council, 2001). Investment in urban expansion, fuelled by large scale urban infrastructure, commercial and residential property development, replaced the previous sectoral policy focus on industries, leading to a new round of city building. Policy makers now tend to see large cities as essential for exploiting of agglomeration economies, with provincial and local governments adapting their policies accordingly. Local governments thus translated this into the creation of growth poles and/or primate cities in various scales to pursue agglomeration economies.

In Henan, the provincial development strategy is increasingly focused on the promotion of Zhengzhou to strengthen its position of primacy within the province. Modelled on the Pudong new district of Shanghai, a series of new urban districts after the ETDZ and HTDZ 
were planned, which were much larger than the existing built up areas (see Table 2). With a planned built up area of $150 \mathrm{~km}^{2}$ and a population of 1.5 million, Zhengdong New District (ZDND), which would double the size of the existing city, was set to be built within 10 years after 2003 (Li, K., 2010; Xue, et al., 2013). Consisting of six large single-function blocks, colocated on large areas of land, with wide road systems and urban functions split by sector, such large scale of urban expansion in such a short period of time attracted international attention when the American CBS TV programme "60 Minutes" labelled ZDND a "ghost city" in 2013 (Pike, et al., 2017). By 2015, however, there had been 1.05 million people registered in the new district with 0.47 million physically living there and more than 100,000 people working in the central business district (ZZSB, 2016). Nevertheless, in contrast to what has been described by the location theory, the gathering of firms and public institutions in ZDND is mainly driven by Henan provincial and Zhengzhou municipal governments. Given the topdown control of the governance system, headquarters of growing enterprises owned by provincial government, banks or their regional headquarters, and the like in the province were required to relocate to ZDND. With incentives such as cheap land, Hukou (or household registration) quotas for housing buyers and their families, ZDND has easily attracted inward investments and migration from the province, which helped the project to meet its planned targets.

Table 2 Phased Urban Expansion in Zhengzhou

\begin{tabular}{llll}
\hline & $\begin{array}{l}\text { Year of } \\
\text { start }\end{array}$ & Location & $\begin{array}{l}\text { Planned areas } \\
\left(\mathrm{km}^{2}\right)\end{array}$ \\
\hline Existing built-up area & By 1987 & 94.2 \\
\hline $\begin{array}{l}\text { Zhengzhou High-Tech Development } \\
\text { Zone }\end{array}$ & 1988 & $\begin{array}{l}\text { Northwest } \\
\text { suburbs }\end{array}$ & 18.6 \\
\hline $\begin{array}{l}\text { Zhengzhou Economic and Technology } \\
\text { Development Zone }\end{array}$ & 1993 & $\begin{array}{l}\text { Southeast } \\
\text { suburbs }\end{array}$ & 12.49 \\
\hline Zhengdong New District & 2001 & $\begin{array}{l}\text { Eastern } \\
\text { suburbs }\end{array}$ & 150 \\
\hline Zhengzhou New District & 2007 & $\begin{array}{l}\text { Eastern } \\
\text { suburbs }\end{array}$ & 150 \\
\hline Zhengzhou Airport Economic Zone & 2007 & $\begin{array}{l}\text { Southeast } \\
\text { suburbs }\end{array}$ & 415 \\
\hline Zhengxi New District & 2015 & $\begin{array}{l}\text { Western } \\
\text { suburbs }\end{array}$ & 72 \\
\hline
\end{tabular}

Sources: Author collected and compiled from various government documents and plans

In 2007, some four years after the ZDND project started, Henan provincial government launched another giant project to develop Zhengzhou airport development zone with a planned area of $138 \mathrm{~km}^{2}$. Three years later, under the national policy of rebalancing regional development, central government approved a larger project expanding the site to $189 \mathrm{~km}^{2}$, drawing on The Rise of Central Region Plan. Further approval was given in 2011 to expand 
the development to cover $220 \mathrm{~km}^{2}$ to support Zhengzhou developing as the central city of the Central Economic Region. In March 2013, as part of the Belt and Road Initiative, Zhengzhou was designated one of the key cities and Zhengzhou Airport was named to be the centre of the "Air Silk Road"2. The central government again nearly doubled the size of the airport development zone while formally designating the $415 \mathrm{~km}^{2}$ Zhengzhou Airport Economic Zone (ZAEZ) as a national strategy to bring about the economic modernization and globalization of one of the nation's largest provinces drawing on the "aerotropolis" model of development (Kasarda, 2015). The airport is planned to have a total of five runways, with one of which dedicated to cargo logistics, capable of handling 70 million passengers by 2030 and over three million metric tonnes of cargo annually by 2020 . The new terminals will be interconnected with a multimodal transportation centre linked to major highways, intercity railways, high-speed railways and underground railways in the metropolitan region. An additional railway station - Zhengzhou South Railway Station comprising 16 platforms with 32 lines - has been built to make the ZAEZ and Zhengzhou a truly integrated international transport hub.

Simultaneously, to support Zhengzhou's emergence as a megacity, Henan provincial government proposed to merge the urban areas of Kaifeng with Zhengzhou, expanding the ZDND eastwards to meet Kaifeng New District. The planned area is $2127 \mathrm{~km}^{2}$, of which $1840 \mathrm{~km}^{2}$ is in the territory of Zhengzhou. Overlapping with the ZAEZ, ETDZ, and ZDND, it is intended to add another four blocks with a total built up area of $150 \mathrm{~km}^{2}$ and a population of 1.52 million by 2020 , bringing a total population of 3.9 million to the area. Moreover, alongside the above initiatives led by the provincial government, Zhengzhou municipal government has planned to promote the western end of the city by converting $72 \mathrm{~km}^{2}$ into urban land and developing a $150 \mathrm{~km}^{2}$ industrial and civic centre, which will accommodate over 1.5 million people by 2020. Altogether, the city's built up area will be expanded to around $1200 \mathrm{~km}^{2}$ with a population of around 10 million by 2020 (ZZMG, 2015) (Figure 3). Benefited once again from being the capital of Henan province, which gives the city the best social infrastructure and economic opportunities over other cities within the province with a population of over 100 million, the planned target of population will be met without doubt. By 2017, the reported population was 9.88 million, an increase of 160,000 from 2016 (ZZSB, 2018), which means the city is likely to reach the 10 million threshold by 2018.

\footnotetext{
2 -- The Rise of Central Region Plan was a national programme after the Development of West Region in 1999 and Renaissance of North-eastern Region in 2004, published by China State Council in 2009 to support growth in Henan, Hubei, Hunan, Jiangxi, Anhui, and Shanxi province.

-- The Development of Central Economic Region was initiated by Henan Provincial Government and endorsed by China State Council in 2011.

-- ZAEZ to develop the Air Silk Road was suggested by China's president Xi Jinping under the Belt and Road Initiative in 2013.
} 


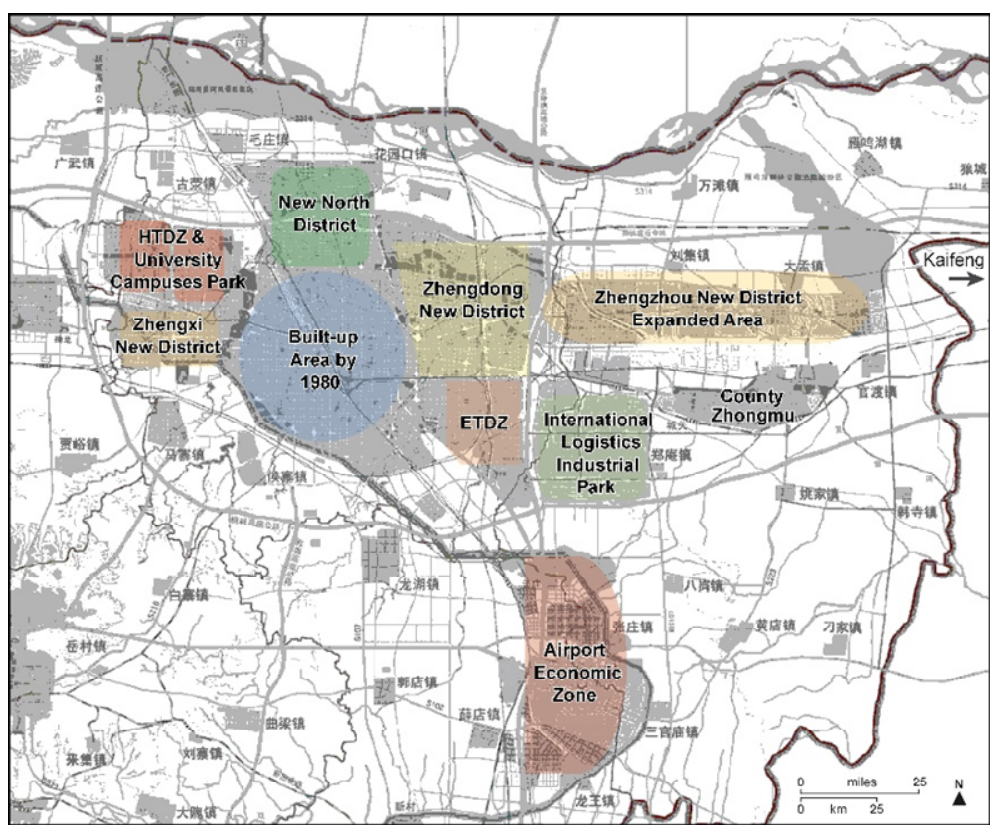

Figure 3 Illustration of Urban Expansion

Sources: Author compiled from major urban development plans

The ambition is underpinned by a series of strategies and industrial policies powered by the central government, including free-trade zone, e-commerce cross-border platform, China Railway Express logistics hub, and special rates of duty and permits for customs clearance system, and so on. These policies were recently repackaged as the national programme supporting Zhengzhou's place in the Belt and Road Initiatives, which aims to develop towards EuroAsian transportation and logistics hub and the international capital of commerce (ZZMG, 2015). Its geographic importance helps it once again gaining the extra support from the central government. Kasarda (2015) notes that Zhengzhou's location as the geographic centre of China's population, where nearly 30 percent of China's GDP is produced within a range of $500 \mathrm{~km}$ of the city, providing airplanes, trains, and motor vehicles with the shortest average travel times to major domestic markets. Zhengzhou has become an advantageous location for logistics industries especially time-critical goods requiring express delivery.

A range of government-led initiatives have accelerated the development. For example, the e-commerce and business platform being supported by an electronic customs clearance system with single-window declaration along with express inspection and export-import clearance allowing users easy to buy from and sell to internationally. Airport cargo volumes expanded from 85,000 metric tons in 2010 to 457,000 metric tonnes in 2016. Several of the world's large logistics companies, such as UPS, DHL, AirBridgeCargo and Cargolux, established distribution centres there (Jiang, 2014). Many of these investments are linked to the presence of Foxconn, the Taiwanese sub-contractor to Apple, which moved its assembly plant from Shenzhen to ZAEZ in 2010. Several tech companies have since clustered in the ZAEZ. Employing 300,000 workers, the cluster produced over 250 million mobile phones 
including more than 100 million iPhone in 2016, contributed 67 per cent of Henan's exports (ZZMG, 2017). Again, the relocation of Foxconn was not because of solely market process, but rather a result of Henan provincial government led bargaining by offering free land-use rights and plant and dormitory buildings which were made ready for moving in within three months after signing the agreement ( $\mathrm{Xu}, 2010)$. In addition, the recruitment of the workforce led by provincial officials and training provided by local governments in Henan province to meet the requirements also played a vital role (Barboza, 2018). Quantifying precisely the real value of the financial incentives provided to Foxconn is hampered by the lack of publicly available data. But, in 2016, the New York Times reported they included discounted energy and transportation costs, lower social insurance payments, grants worth more than US\$1.5 billion for the construction of factories and workers' accommodation and provided a US\$250 million loan to Foxconn.

Rapid urban expansion requires massive investment in infrastructure. However, after the fiscal reform in 1994, a series of new responsibilities have been placed on local governments, but without decentralisation of fiscal autonomy and financial resources. Local governments, therefore, have become heavily reliant on generating so-called "extrabudget" revenues to fulfil the devolved responsibilities. Borrowing from the shadow banking system and selling land-use rights are the two largest sources of finance used by local governments (OECD, 2009; Wang, X., 2014; Zhang, 2014). During the period from 1999 to 2016, while local governments debt accumulated, risking financial stability, annual extrabudget revenue made from selling land-use rights increased from RMB 51.4 billion (US\$ 6.21 billion) in 1999 to 3.75 trillion (US\$ 564.56 billion) in 2016, driving the ratio of local budgetary revenue from 9.19\% to 42.96\% (CMF, 2017; McKinsey Global Institute, 2015).

In Zhengzhou, local government debt is mainly in the form of direct borrowing from locally controlled banks and loans against land from large commercial banks. Comprehensive longitudinal data are not available, but the local congress' approval to convert unrepaid loans to local treasury bonds may tell the part of the story. In 2015 and 2016, Zhengzhou Municipal Government converted RMB39.48 billion (US\$ 6.34 billion) and RMB45.4 billion (US\$ 6.83 billion) bank loans to treasury bonds, accounting for $101 \%$ and $108 \%$ of its annual fiscal revenue respectively (ZZFB, 2016, 2017), although it is likely that the value of total debt is much higher. The annual land use review shows that loans made on land in 2015 were recorded at RMB 57.87 billion (US\$ 9.29 billion), 1.47 times of its fiscal revenue in that year (ZZLRB, 2016). Meanwhile, through public-private partnerships (PPP), a policy tool developed since 2015, Zhengzhou contracted RMB394.8 billion (US\$ 63.39 billion) and RMB699.0 billion (US\$ 105.23 billion) for infrastructure investments in 2015 and 2016 respectively, both again have significantly exceeded its fiscal revenue (ZZFB, 2016, 2017). The pressure brought by fast growing debt had directed local government to rely increasingly on land financialisation. Partially released documents show that within 10 years, the net income made from selling land-use rights increased from RMB1.74 billion (US\$ 0.22 billion), $14.2 \%$ of fiscal revenue in 2007, to RMB49.62 billion (US\$ 7.47 billion), more than 1.18 times of its fiscal revenue in 2016 (ZZFB, 2017). This has been achieved through selling more land and forcing up land prices. Both, however, have reached their 
limit because the allowance of land conversion had been exceeded year after year and house prices are already out of reach of many households (ZZLRB, 2016).

\section{Challenges ahead}

Zhengzhou's recent rapid rise throws up some severe challenges. First, spatial enlargement of the urban area without a systematic and research-based long-term plan has led to disorderly urban sprawl (see details in Mu, et al., 2016). Planning, in the Chinese context, is both a political and technical exercise without a statutory basis. Political leaders use the FYP to promote their interests; urban plans serve as technical exercises to meet the output targets set in the FYP. Very often, this is translated into an approach where plans are subject to short-term political decision-making by local leaders under competitive pressure to meet their own targets. This is obvious in Zhengzhou. Establishing the HTDZ in 1988, the ETDZ in 1993, the ZDND in 2001, the ZAEZ in 2007 and the subsequent developments, notably Zhengzhou-Kaifeng new district in 2009, and the western new district in 2015, represent different priorities of development emphasised by different leaders at the time. But their relationships with the existing areas and between them have rarely been properly considered when each decision was made to develop a new area, which is arguably the main cause behind the problems facing today, such as traffic congestion.

Second, the success of urban development in the long-run rests ultimately on its quality, not just its quantity. Whereas economic development refers to the increase of productivity, skills, incomes, and embedded innovation and creativity, growth may be simply a result of increase output. Zhengzhou's rapid economic growth in recent years relies heavily on investment in infrastructure and manufacturing. However, both have now become problematic. Investment in infrastructure is funded mainly by the revenues from sales of land-use rights. This has been the driving force for spiralling housing prices in Zhengzhou's newly developed areas, making housing unfordable for most working families but a subject for speculative investment for a rich few (Scott, 2016). At the same time, mobile investment attracted from elsewhere to the newly established industrial zones in Zhengzhou, is far from embedded in the region. Even those labelled as "high-end manufacturing" add little to the innovative capacity of the economy. Much development is best described as a "branch plant economy" taking the advantages of lower labour costs, but such advantages have been increasingly eroded because of the rapid increase of wages. Moreover, despite the massive property development and low occupancy rates, migration workers attracted by opportunities in the mobile factories and the labour-intensive sector find it difficult to live in the city either because they cannot afford to own home or because they lack Hukou rights. This population group was estimated to be around 1.5 million in 2015 (ZZSB, 2016).

Third, Zhengzhou's fast growth is best explained by the co-effect of state-directed capitalism and state-sponsored neoliberalism (Chu \& So, 2010; The Economist, 2012). While the former, using the state power, placed the city in a privileged position, benefiting from the special support both from the provincial and central governments, the latter allows the city more autonomy in making decisions about urban development. In the context of Chinese 
governance, state-sponsored neoliberalism is challenging the authoritarian state capitalism, particularly, in circumstances where local officials see progress as linked to economic performance and favourable growth rankings, creating the conditions for fierce interjurisdictional competition (Pike, et al., 2017). Zhengzhou's competitive advantages drawing on the designation of conducting various national experiments are challenged by competing initiatives elsewhere, such as Changsha, even within the province. Meanwhile, its "low road" approach to economic development based on attracting mobile investment places it in the vulnerable position when labour costs rise.

Fourth, rapid urban sprawl has generated severe environmental pressures. Although sustainable urbanisation has been widely deployed since the State Council's New-Approach to Urbanization Plan (2014-2020), it is trumped by a much stronger and deeper commitment to a narrower focus upon economic output targets. Zhengzhou suffers from severe problems of urban pollution and is regularly ranked among the 10 worst places in China for particulate matter and growing rates of respiratory disease (OECD, 2015). The worsening air pollution has emerged as a pressing political problem hence prompted the national Ministry of Environmental Protection to introduce a rule allowing it to summon local leaders for warning discussions about the situation. The mayor of Zhengzhou was called to a meeting in 2015 (Li, J., 2015). In 2015, to suppress dust, Zhengzhou city authorities had to use 3.5 million tonnes of imported water every day to deal with haze (People's Daily Online, 2015). Although the Ministry of Housing and Rural-Urban Development required Zhengzhou (along with 13 other cities) to designate an urban growth boundary (China Daily, 2015), but there are both political and governance obstacles to making these measures effective (OECD, 2015).

Finally, despite the State Council's call for "people centred" urbanisation, the governance system and the systematically developed and deeply rooted assessment criteria of local performance continue to prompt local decision makers to focus on narrowly defined economic growth targets, fuelling unchecked territorial competition. This has been translated into a state entrepreneurial approach to urban development. The pressing problems facing most Chinese cities today are the shortage of social infrastructure and the sky-high housing prices. Both are arguably a result of state entrepreneurialism. City governments expect to attract industrial investment through prioritising investment in economic infrastructure, but land financialisation drives up the land prices and the costs of providing social infrastructure. Many planned social infrastructure and facilities have never been built because of lack of funds. In Zhengzhou, investment in fixed assets ${ }^{3}$ has increased ninefold from RMB 50.04 billion (US\$ 6.05 billion) in 2003 to RMB 450.93 billion (US\$ 71.69 billion) in 2013 and built-up urban area expanded almost doubled from $212.4 \mathrm{~km}^{2}$ to $382.7 \mathrm{~km}^{2}$. But the numbers of primary and secondary schools have dropped from 1489 to 355 and 980 to 268 respectively, although the number of pupils are fluctuated increasing (ZZSB, 2016). House prices, on the other hand, have grown three times faster than average income growth.

\footnotetext{
${ }^{3}$ Data on investment in social and economic infrastructure are not available, but investment in fixed assets provide a proximation.
} 


\section{Conclusion}

The rapid recent growth of Zhengzhou, which leaves it on the cusp of megacity status, has been both impressive and distinctive. Agglomeration economies arising from market process used to explain urban growth elsewhere, provide, at best, a partial account of Zhengzhou's growth. Globalisation and innovation increasingly provide the context for urban development, but geography, natural endowments, politics, institutions, history, and economic structure, continue play a key role. This is particularly the case in the context of an authoritarian economy. The rise of Zhengzhou from a small town to megacity in less than seven decades has reflected its geographical location and its status as the provincial capital of Henan in China's multi-level governance system. Support from the provincial and central government has been critical to speed and nature of Zhengzhou's development. The ambitious plan to create a EuroAsian transportation and logistics hub and an international capital of commerce underpinned by the fast-growing e-commerce cross-border trade and related logistics industries offers development potential. But with the weak embeddedness of leading enterprises and limited endogenous innovation, raise questions about the resilience of this mode of development. The recent shift to a kind local state-sponsored neoliberalism, with its tendency to wasteful forms of territorial competition raises additional concerns. Rising environmental costs and growing social exclusion and intra-urban inequalities are clear threats. In the face of these, innovation and reform in governance, is necessary if Zhengzhou is to develop towards a well-functioning megacity.

\section{Acknowledgements}

This work is part of the outputs of the project funded by Economic and Social Research Council [grant number: ES/J019232/1]. We would also like to thank Henan Academy of Social Science for access to archived data.

\section{References}

Barboza, D (2016) "How China Built 'iPhone City' With Billions in Perks for Apple's Partner"< New York Times, 29 December' https://www.nytimes.com/2016/12/29/technology/appleiphone-china-foxconn.html. Accesssed 16 Jul7 2018

China Daily (2015). 14 cities to draw red line to stop urban sprawl. News http://en.people.cn/n/2015/0605/c90882-8902762.html. (accessed 18 January 2017 ) China State Council (2001). The Tenth Five-Year Plan for Scoial and Economic Developemnt. Beijing. The People's Congress of China.

Chu, Y. W., \& So, A. Y. (2010). State neoliberalism: the Chinese road to capitalism. In Chinese Capitalisms, 46-72: Springer.

CMF (2017). Fiscal Revenues and Spending in 2016 Beijing. China Ministry of Finance. 
Jiang, S. (2014). Once a railway town, Zhengzhou now busy air hub thanks to 'Applemania'. 10 September Hong Kong. South China Morning Post.

http://www.scmp.com/business/china-business/article/1589196/once-railway-townzhengzhou-now-busy-air-hub-thanks. (accessed 16 December 2016)

Kasarda, J. (2015). Zhengzhou Airport City. Site Selection. 74-77.

$\mathrm{Li}$, J. (2015). China's Environmental Chiefs Summon Zhengzhou Mayor over Worsening Smog 29 July Hong Kong South China Morning Post http://www.scmp.com/news/china/policiespolitics/article/1844918/chinas-environmental-chiefs-summon-zhengzhou-mayor-over. (accessed 16 January 2017)

Li, K. (2010). The Master Plan for Zhengdong New District Beijing: China Construction Industry Press.

Liu, J. (1984(1929)). New Chronicles of Henan. Zhengzhou: Zhongzhou Archive Press. Liu, Y. (1988). Urban Development in Contemporary Zhengzhou. Beijing: China Construction Industrial Press.

Liu, Y., Zhao, R., \& Xu, M. (2008). Analysis of Spatial Structure Changes of Zhengzhou Modern Urban Research, 61-66.

McKinsey Global Institute (2015). Debt and (Not Much) Deliveraging. London: Mckinsey \& Company.

Mu, B., Mayer, A.L., He, R., and Tian, G. (2016). Land Use Dynamics and Policy Implications in Central China: A Case Study of Zhengzhou. Cities, 58, 39-49.

Naughton, B. (1996). Growing Out of the Plan: Chinese Economic Reform, 1978-1993.

Cambridge University Press.

OECD (2009). Trends in Urbanisation and Urban Policies in OECD Countries: What Lessons for China? Paris. Organisation for Economic Co-operation and Development.

OECD (2015). OECD Urban Policy Reviews: China 2015. Paris. Organisation for Economic Cooperation and Development.

People's Daily Online (2015). Zhengzhou uses 3.5 million tons of water every day to deal with haze News http://en.people.cn/n/2015/0814/c98649-8936273.html. (accessed 26 January 2017)

Pike, A., Rodríguez-Pose, A., \& Tomaney, J. (2017). Local and regional development. Routledge.

Qin, Q. (1992). A Study of the "War on Zhengzhou Commercial Sector" and the Phenomenon of Asia Department Store (in Chinese). Commercial Economy Studies, 23-25.

Scott, D. (2016). If You Think China's Stock Bubble Was Nuts, Look at What's Now Happening in its Property Market. Australia Business Indsider.

Shigejiro (1921). Business Intelligence of Zhengzhou Yokohama Yokohama Specie Bank The Economist (2012). The Rise of State Capitalism. The Economist London.

Wang, X. (2014). China's Local Public Finance in Transition. International Planning Studies, 19, 99-101.

Wang, X. S., Dong, G. P., \& Mao, H. (2005). The Urban Development Process and Its Feature of Zhengzhou City. Areal Research and Development, 24, 47-51.

Wu, Y., \& Zhang, J. (2009). A Brief Analysis of the Rise and Fall of State Owned Enterprises: The case of Zhengzhou textile industry. China Reform Forum, 38-39.

Xu, J. (2010) 'Foxconn Surprised by "Zhengzhou Speed" ', Dahe Daily 16 December 2010. http://newpaper.dahe.cn/hnrb/html/2010-12/16/content 436489.htm (accessed 16 July 2018) 
Xue, C.Q.L., Wang, Y., and Tsai, L. (2013). Building New Towns in China - a Case Study of Zhengdong New District. Cities. 30, 223-232.

Zhang, Z. (2014). The Impact of Local Government Debt on Local Economic Growth - The Case of Zhengzhou. Wuhan Finance, 4-7.

ZZCEG (1990). Zhengzhou Chronicles Zhengzhou: Central China Cultural Press.

ZZFB (2016). Annual Fiscal Report 2015. Zhengzhou. Zhengzhou Finance Bureau.

ZZFB (2017). Annual Fiscal Report 2016. Zhengzhou. Zhengzhou Finance Bureau.

ZZLRB (2016). An Analysis of Land Use in 2015. Zhengzhou. Land and Resources Bureau of Zhengzhou.

ZZMG (1989). Fourty Years of Zhengzhou Since 1949. Zhengzhou. Zhegnzhou Municipal Government.

ZZMG (2015). The Plan for Developing towards International Commercial and Business City. Zhengzhou: Zhengzhou Muncipal Government.

ZZMG (2017). Annual Work Report to the People's Congress. Zhengzhou: Zhengzhou Municipal Government.

ZZSB (2016). Zhengzhou Statistic Yearbook. Zhengzhou. Zhengzhou Statistic Bureau. ZZSB (2018). Zhengzhou Statistic Annual Report, Zhengzhou, Zhengzhou Statistic Bureau. 